\title{
The Use of Concrete Media in Science Learning in Inquiry to Improve Science Process Skills for Simple Machine subject
}

\author{
Muhamad Taufik Bintang Kejora \\ Faculty of Islamic Studies, Universitas Singaperbangsa Karawang, \\ Karawang city, West Java, Indonesia \\ Email:muhamad.taufik@fai.unsika.ac.id
}

\begin{abstract}
This study aims to determine the improvement of science process skills with the media using concrete in science learning by inquiry. The study was conducted using a quasi-experimental design with a nonequivalent control group design. In the experimental group applied to learn to utilize concrete media in learning science in an inquiry, while the control class applied to conventional learning utilizing audio-visual media. Subject: The study included 60 students of class V Elementary School performances in Purwakarta district. The test results for the normalization gain skills enhancement process gain values obtained experimental class ( $\mathrm{N}$-gain 0.46) is greater than the value of the class gain control ( $\mathrm{N}$-gain 0.17). Based on the test results mean difference two improvements by using the t-test, obtained $t=2.688>$ table $=2.045$, with sig. $0.012<\alpha<0.05$ then $\mathrm{H}_{0}$ is rejected and Ha. Therefore, inquiry science learning by utilizing concrete media can significantly improve students' science process skills.
\end{abstract}

Keywords: Concrete Media, Inquiry learning, Science Process Skills, Elementary School

\section{INTRODUCTION}

Natural Sciences is a branch of science that plays an important role in the development of science and technology. Samatowa (2010) explained that natural sciences discuss natural phenomena systematically arranged based on the experimental results and observations made by man. So, that these 
aspects can be achieved by the students well, of course in learning should be chosen media, models, strategies, methods and approaches right, so that the process occurs debriefing and training of science process skills.

The students' skills in science learning processes need to be developed. So, students can find their concepts to understand the material and improve learning outcomes. Science process skills are important for students as a provision in studying phenomena that occur in nature with specific ways to gain this knowledge and be useful in the development of the next (Franestian et al., 2020; Shahali et al., 2015).

One of the components that can be measured to access students' science process skills is the ability to access the inquiry. The inquiry learning has focused on the activities and the provision of learning experiences directly to the students. National Education Standards Agency (BSNP, 2006) stated that learning science in elementary school or Sekolah Dasar (SD)/Madrasah Ibtidaiyah (MI) scientific inquiry should be conducted (scientific inquiry), it is intended to raise the ability of scientific work, scientific attitude, and be able to communicate as critical components in life skills.

But, the reality on the field application of science process skills is not yet optimal. It is based on a study done by Yusuf (2016) in his study that: (1) $80.7 \%$ science teaching is done by a lecture and exercises aided worksheets that more emphasis on the macroscopic and symbolic; (2) $59.2 \%$ of science teachers manage to learn with material delivery in verbal patterns (3) $85.2 \%$ of science teachers adopt the direct order of the subject 


\section{Mudarrisa: Jurnal Kajian Pendidikan Islam, Vol. 12, No. 1, 2020}

matter in the book that is used and (4) $23.1 \%$ of science teachers ever doing practical nature verification, not an investigation.

The skills science teaching process is a problem that must be improved to overcome some subjects that have a specific problem, especially for the simple machine. A simple machine has the function to make human work easier. Simple machines have 4 types are lever (lever), the inclined plane, wheel, and pulley. The purpose of using the simple machine is to 1) redouble our ability style or, 2) to change the direction of the force that we did, and 3) a long distance away or speed increasing.

The direct learning, experiences, discovery about the phenomenon were needed to improve the student's competencies and achievement. One way to improve science process skills in science teaching is through the use of media in learning (Martiningsih et al., 2019; Rambousek et al., 2016). One media deemed appropriate is a concrete media

Learning by using concrete objects media is more capable of providing real experiences to students because students can see, taste, and feel the props used. The concrete learning experience would be more suitable for elementary school/madrasah level. The advantages of using concrete media in learning for students are 1) provides the opportunity for students to learn about the real situation, 2) enhancing student interest in the subject matter, and 3) train the skills of students using the senses (Yusuf, 2016).

The science inquiry teaching aims to encourage the ability to think, work, scientific skills, and communicate as an important aspect of life 
skills (Savitri et al, 2017). The question activities are observed, classify, interpret, predict, plan research, apply, ask questions, and communicate (Soto \& Ambrose, 2016). It can imagine if these activities are not trained in science learning then students will not be able to explain how a phenomenon could occur. Also, students will have difficulty in the next level because of the higher levels of the science process skills are increasingly complex.

Pratiwi found the result in their Classroom Action Research design of Kemmis and Taggart that learning simple plan material by using Inquiry Learning determine the student activity and the result of students' learning completeness at percentages of $44.0 \%$ in cycle I; $70.0 \%$ in cycle II; and $87.0 \%$ in cycle III, while for teacher's performance at percentages of $75.0 \%$ in cycle I; $87.5 \%$ in cycle II; and $100.0 \%$ in cycle III. Student learning outcomes in cycle I reached a percentage of $48.0 \%$ in cycle I; $70.0 \%$ in cycle II; and $87.0 \%$ in cycle III. While Nuraida (2016: 26) in Classroom Action by using the experimental method in studying simple plan material found that there is an enhancement of students' results of learning (Ananda \& Fadhilaturrahmi, 2018; Pratiwi et al., 2017). There were $8.0 \%$ ( 2 students) who gained the minimum standard, $44.0 \%$ (11 students) in cycle I, 92.0\% (23 students) in cycle II.

The purpose of this study was to determine to enhance the science process skills of students with the use of concrete media in science learning by inquiry. Materials science subjects in this study are limited to the simple machine subject which learned in class $\mathrm{V}$ of madrasah level 
covering material levers, inclined planes, pulleys, and wheels pivot. Science process skills were examined in this study is limited to four aspects: 1) formulating experiments, 2) inquiry, 3) to formulate hypotheses, and 4) Predict.

\section{METHODS}

This study uses a quantitative approach. The method used in this research is quasi-experimental methods (quasi-experiment) and research design Non-equivalent Control Group Design. This design comparing the value of the pretest-posttest experimental class was given treatment using concrete media in science learning in inquiry and pretest-posttest control group was given treatment using audio-visual media in conventional science teaching as formula below:

$$
\frac{\text { Experiment }}{\text { Control }}=\frac{01 X 102}{P 1 X 2 P 2}
$$

(Sugiyono, 2016)

Info:

$\mathrm{O} 1=$ pretest science process skills students (experimental group)

$\mathrm{O} 2$ = posttest science process skills students (experimental group)

$\mathrm{X} 1=$ Treatment in inquiry science learning that utilizes concrete media

$\mathrm{X} 2=$ Treatment conventional science teaching aided audio-visual media

$\mathrm{P} 1$ = pretest science process skills students (grade Control)

$\mathrm{P} 2$ = posttest science process skills students (grade Control) 
The selected population is all students of class $\mathrm{V}$ in $\mathrm{MI}$ those performances spread over two classes of each 60 students. For selecting, the amount of 30 students used as an experimental class and 30 students in grade $\mathrm{B}$ as the control class. The experimental class stated as class $\mathrm{V}$-a with 30 students used the concrete media in learning science as inquiry. The control class stated as class V-B with 30 students in conventional science teaching methods by audio-visual media.

Learning tools used in the form of lesson plans, worksheets, and simple machine concrete media. As for the instruments or means of collecting data, this study of a test to examine the science process skills (PPP) and the observation sheet to determine the extent of adherence to the stages of learning media utilization of concrete in science learning by inquiry (Wati \& Novianti, 2016). Before the test instrument used for data collection science process skills, the first test in the form of instrument was carried out validity test, reliability test, test, and test distinguishing the level of difficulty. The research was conducted in three phases, namely: (1) preparation, (2) implementation, and (3) The final stage.

The data has been obtained and analyzed quantitative method. In statistical data processing, utilizing the software application Statistical Product and Service Solutions (SPSS) 25.0 for Windows, Steps to carry out data analysis: 1) Scoring Pre Test and Post Test; 2) Data Processing results of observations to the Learning Model; 3) Analyze similarities Mean between the two classes; 4) Test Normality test by Kolmogor of-Sminorv; 5) Homogeneity test; and 6) test Two mean difference using paired sample 
test, and 6) Calculation of average $\mathrm{N}$-gain using the gain following formula:

$$
<\mathrm{G}>=\frac{(\text { S post }- \text { S Pre })}{(\text { mid }- \text { S Pre })}
$$

Info:

$\mathrm{g} \quad=$ average score gain normalized

$\mathrm{S}_{\text {post }}=$ posttest scores

$\mathrm{S}_{\text {pre }}=$ pretest scores

$\mathrm{S}_{\mathrm{mid}}=$ ideal maximum score

Then the value of $g$ consulted in the table to interpret $\mathrm{N}$-gain and its categories as shown in Table 1.

Table 1. The $\mathrm{N}$-gain internal value and criteria

\begin{tabular}{lc}
\multicolumn{1}{c}{ Interval N-gain } & Categories \\
\hline $\mathrm{g}<0.3$ & Low \\
$0.3 \leq \mathrm{g} \leq 0.7 \mathrm{~g}$ & moderate \\
\hline $\mathrm{g}>0.7$ & High \\
\hline
\end{tabular}

In this study, the norms imposed categorization value science process skills with the following criteria: very poor, poor, pretty good, good, and excellent. Grouping of research data refers to the categorization criteria Muhibbin Shah (2011) was shown in Table 2.

Table 2. Criteria for Class Assessment based scoring

\begin{tabular}{ccc}
\hline No. & Score & Criteria \\
\hline 1. & 0 to 49.99 & Very less \\
\hline 2. & 50 to 59.99 & Not good \\
\hline 3. & 60 to 69.00 & Pretty good \\
\hline 4. & 70 to 79.99 & Good \\
\hline 5. & $80-100$ & Very good \\
\hline
\end{tabular}




\section{DISCUSSION}

\section{Activities of science learning in inquiry}

The teacher's activities in the inquiry methods were done by concrete media that consisted of orientation; problem formulating, hypothesis formulating, collecting data, hypothesis testing, conclusions, and the final activity (Konita et al., 2015). The inquiry process was carried out by the student in the classroom. In the activity, teachers supported them to find out the science object in some specific cases. Afterward, the teacher asked them to decide what they analyzed. It supported them to be more creative in thinking (Suduc et al., 2015).

\section{Student activity}

By the observations during the learning activities, at the first session, second, third, and fourth looks are not all of the students are actively involved in research activities. In the first, second, third, and fourth sessions, most students are actively involved in researching appropriate activity worksheets that have been provided, but some students mislaid their concentration and were busy playing with the others. It was very likely because students are in one group so much that not all students can get involved in doing research. Students who did not get the role, whether it holds the tool or holding the worksheet (LKS) and writes occasionally seen chatting with friends or doing their activities that have nothing to do with research activities (Susialita, 2016; Yustina, 2017).

Another lack is the teachers too long stay in one group (to help the

group difficulties), so sometimes other groups waiting for the arrival of 
teachers because there are things that are not understood by him feel bored because it was not addressed. It also led to more and more students are chatting or doing other activities that are not related to teaching and learning.

This incident resulted in a lack of mastery of the material by students who are not actively involved in research activities so that the value of some students was satisfactory and increased ability to both mastery of concepts and skills of its scientific process is not very good (not too high). It becomes its record and must be considered by the teachers who will carry out the learning activities through research.

\section{Science Process Skills}

Science process skills test as many as 17 questions given to student's experimental class and control class, in the form of test initial and final tests science process skills. The material was tested on a simple plane includes a lever, inclined plane, pulley, and wheel pivots. The Aspects of science process skills measured are formulating an experiment, ask questions, formulate hypotheses, an experiment is to plan and predict.

To see the science process skills, an improvement that has been achieved by the student and qualification data used score gain is normalized (N-gain). Improved science process skills that are described in this bargain consists of a general increase and improvement to every aspect of science process skills. The results of the science process skills in the experimental class and control class were shown in Table 3. 
Table 3. The achievement of the science process skills PPP per Dimensions

\begin{tabular}{cccccccccc}
\hline No. & Science & \multicolumn{4}{c}{ Control } & \multicolumn{5}{c}{ Experiment } \\
\cline { 3 - 9 } & $\begin{array}{c}\text { Process } \\
\text { Skills }\end{array}$ & pre & posts & gain & Category & pre & posts & gain & Category \\
\hline \multirow{1}{1}{$\begin{array}{c}\text { formulate } \\
\text { Trial }\end{array}$} & 63.33 & 70.56 & $0: 20$ & Low & 57.78 & 82.78 & $0: 59$ & moderate \\
\hline 2 & Asking & 58.33 & 65.83 & $0: 18$ & Low & 72.50 & 86.67 & $0: 52$ & moderate \\
\hline 3 & $\begin{array}{l}\text { formulate } \\
\text { hypothesis }\end{array}$ & 57.50 & 59.17 & $0: 04$ & Low & 55.83 & 70.83 & $0: 34$ & Low \\
\hline 4 & Predicting & 61.11 & 72.22 & $0: 29$ & Low & 65.56 & 75.56 & $0: 29$ & Low \\
\hline & GAIN & & & $0: 17$ & Low & & & $0: 46$ & moderate \\
\hline
\end{tabular}

After learning the results of the final test average science process skills of students in the experimental class that implements a science inquiry learning by utilizing concrete media showed a higher increase than the control class that implements conventional science teaching by audiovisual media (Ngurah \& Laksana, 2017). The N-Gain Index science process skills class students' experiment (0.46) was included in the medium category and $\mathrm{N}$-Gain control class science process skills $(0.17)$ including the low category.

Sciences process skills data on two classes of $\mathrm{N}$-gain data and test requirements analysis in the form of normality and homogeneity test. The results are shown in Table 4.

Table 4. Normality Test and and Test Homogeneity

\begin{tabular}{|c|c|c|c|c|c|c|}
\hline \multirow{2}{*}{ Class } & \multirow{2}{*}{ Score } & \multirow{2}{*}{ Average } & \multicolumn{2}{|c|}{ Normality test } & \multicolumn{2}{|c|}{ Homogeneity test } \\
\hline & & & Sig & result & Sig & Result \\
\hline \multirow{2}{*}{ Experiment } & pre & 62.16 & 0.56 & Normal & \multirow{2}{*}{0.649} & \multirow{2}{*}{ Homogeneous } \\
\hline & Post & 79.61 & 0.52 & Normal & & \\
\hline \multirow{2}{*}{ Control } & pre & 60.39 & 0.23 & Normal & \multirow{2}{*}{0.236} & \multirow{2}{*}{ Homogeneous } \\
\hline & Post & 67.06 & 0.47 & Normal & & \\
\hline
\end{tabular}


Mudarrisa: Jurnal Kajian Pendidikan Islam, Vol. 12, No. 1, 2020

\begin{tabular}{|c|c|c|c|c|c|}
\hline gain Experiments & 0.46 & 0.902 & Normal & \multirow{2}{*}{0.257} & \multirow{2}{*}{ Homogeneous } \\
\hline gain Control & 0.17 & 0.181 & Normal & & \\
\hline
\end{tabular}

Based on the data clearly shows that the two classes of data and data gain to aspects of science process skills normalized homogeneous data it can be seen from the significantly less or equal than 0.05. Analysis of the data continued to test hypotheses about differences in learning science process skills improvement in inquiry utilizing conventional learning by using audio-visual media. The hypothesis formulated in the form of a statistical hypothesis test of the difference in an average increase in science process skills ( $\mathrm{N}$-gain) between the experimental class control classes.

$\mathrm{H}_{0}: \mu_{1}=\mu_{2}$

$H_{\mathrm{a}}: \mu_{1} \neq \mu_{2}$

By explanation below:

$\mathrm{H}_{0}$ : There is no significant difference between the increase in science process skills of students receive instructional media utilize concrete in a science inquiry learning with conventional learning by using audio-visual media.

$\mathrm{Ha}$ : There are significant differences between the increase in science process skills learning students who utilize concrete media in a science inquiry learning with conventional learning by using audiovisual media.

Based on the calculation, the t-test value was 2.688 at the significance level or $\alpha$ of 0.05 with degrees of freedom $d f(29)$ so t-table $(29)=2.045$. By looking at the results of $\mathrm{t}$ and $\mathrm{t}$ table it is seen that $\mathrm{t}=2.688>\mathrm{t}_{\text {table }}=2.045$, 
with sigma was an amount in $0.012<\alpha<0.05$ then it could be said that $\mathrm{H}_{0}$ is rejected and $\mathrm{Ha}$ accepted which means that there are differences in average science process skills in the application of learning to use the media as a concrete inquiry science learning with conventional learning by using audio-visual media. The hypothesis test result was shown in Table 5.

Table 5. Hypothesis Test Results

\begin{tabular}{|c|c|c|c|c|c|}
\hline Class & Score & Average & $t$-Count & $t$-table & Sig \\
\hline $\begin{array}{c}\text { Experiment } \\
\text { Control }\end{array}$ & $N$-gain & $\begin{array}{l}0.46 \\
0.17\end{array}$ & 2.688 & 2.045 & 0.012 \\
\hline
\end{tabular}

As the results of different test average N-Gain experimental class (0.46) proved to be greater than the $N$-class Gain controls (0.17). It could be concluded that learning to use the media in a concrete inquiry science learning in further enhancing science process skills compared with conventional learning by using audio-visual media. Science learning showed some natural change, so it would be better if the teacher did visualization the topic. Students would be more understand that talk in front of the class. In the learning activity, concrete media helped the students to understand the science subject (Dewi, 2018; Hardini \& Akmal, 2017).

The inquiry learning process can help the teachers and students to construct their knowledge well because they do it themselves, not only by textbooks only. The simple machine subject was one of the science subjects that need the student's creativity. Student creativity is the main of 


\section{Mudarrisa: Jurnal Kajian Pendidikan Islam, Vol. 12, No. 1, 2020}

science learning by its object and the key to the 2013 curriculum (Zulkarnaen et al., 2017).

Learning science as an inquiry by the media using the concrete course will be able to further enhance the improvement of science process skills compared to science teaching is conventionally due to the class implementing science learning in the inquiry by using concrete media is students construct the work of scientists in discovering knowledge following a constructivism learning theory (Staddon, 2017; Yustina, 2017). Inquiry learning provided opportunities for students to be more flexible in independent learning, exchanging minds with each other and help each other to complete each task assigned by the teacher.

Yusuf (2016) explains there are some mental operations in any activity undertaken by each person. The mental operations is a skill that includes observing, communicating, classifying, inferring, measuring, and experimenting. Skill is what is called the science process skill (PPP) because scientists use these skills in their work processes. In science, the scientists found the course through several procedures including formulating an experiment, ask questions, formulate hypotheses, planning experiments, and predict (Duruk et al., 2017; Peyrefitte \& Lazar, 2018).

So, students more easily understand science lessons, the most appropriate step is to reconstruct the scientists' work in finding the natural sciences is to research to find their little science. To find the knowledge that some basic skills must be mastered by the student (as controlled by scientists) namely; skills and interfere observe, measure and estimate, 
categorize and classify, organize and presentation the data, predict and hypothesize, provide operational definitions, identify and control variables, as well as conducting experiments and investigations (Erlinayaumas et al., 2018; Unver, 2018). After doing science learning in the inquiry by the media using concrete, then the science process skills test. The skill test was done by the teacher by using concrete media and classroom learning process related.

\section{CONCLUSION}

Based on the analysis, the science process skills improvement group of students who received the inquiry learning that utilizes concrete media is higher than the group of students who get conventional science teaching aided by audio-visual media. Nevertheless, there are still many obstacles to its implementation. Utilization of concrete running less optimal media, so expect a better learning plan following the stages of the execution plan of learning by making use of the media in the stage of concrete and then integrate and combine it with the stages of inquiry science process skills so that learning can be done in an integrated manner. The research instruments, before the instrument, is used needs to be done about the item analysis indicators to notice conformity with context about the mastery of concepts and science process skills. Additionally, the teacher is expected to devise a medium of learning in conventional learning to improve science process skills. 


\section{REFERENCES}

Ananda, R., \& Fadhilaturrahmi. (2018). Peningkatan Kemampuan Sosial Emosional Melalui Permainan Kolaboratif pada Anak KB. Jurnal Obsesi: Jurnal Pendidikan Anak Usia Dini, 2(1), 20-26.

Dewi, L. P. P. (2018). Penerapan Model Pembelajaran Quantum Teaching berbantuan Media Konkret untuk Meningkatkan Hasil Belajar IPA. Journal of Education Action Reseach, 2(1), 23-29. https://doi.org/http://dx.doi.org/10.23887/jear.v2i1.13727.

Duruk, U., Akgün, A., Doğan, C., \& Gülsuyu, F. (2017). Examining the Learning Outcomes Included in the Turkish Science Curriculum in Terms of Science Process Skills: A Document Analysis with Standards-Based Assessment. International Journal of Environmental $\mathcal{E}$ Science Education, 12(2), 117-142.

Erlinayaumas, N., Syafril, S., Noor, N. M., Mahmud, Z., Umar, J., Wekke, I. S., \& Rahayu, T. (2018). The Importance of Counselling Basic Skills for the Counsellors. International Journal of Pure and Applied Mathematics, 119(18), 1195-1207.

Franestian, I., Suyanta, \& Wiyono, A. (2020). Analysis of problem solving skills of students in Junior High. In Journal of Physics: Conference Series (p. 1440). https://doi.org/10.1088/1742-6596/1440/1/012089.

Hardini, A. T. A., \& Akmal, A. (2017). Penerapan Metode Snowball Throwing berbantuan Media Konkret untuk Meningkatkan Keaktifan dan Hasil Belajar IPA Siswa Kelas IV Sekolah Dasar. Jurnal Pendidikan Dasar PerKhasa, 3(April), 233-245.

Konita, A. P., Suyanto, I., \& Suhartono. (2015). Penggunaan Model Project Based Learning dengan Media Benda Konkret dalam Peningkatan Pembelajaran IPA pada Siswa Kelas IV SDN Pucung Kidul 03 Tahun Ajaran 2014/2015. Kalam Cendekia, 3(1), 167-169. Martiningsih, I., Mulyani, S., \& Susilowati, E. (2019). Journal of Innovative Science Education Development of Module Based on Scientific Contextual Additives Material to Increase Learning Outcomes and Science Process Skills in Junior High School. Journal of Innovative Science Education, 8(2), 128-137. https://doi.org/DOI 10.15294/JISE.VOIO.27790.

Ngurah, D., \& Laksana, L. (2017). The Effectiveness of Inquiry Based 
Learning for Natural Science Learning in Elementary School. Journal of Education Technology, 1(1), 1-5. https://doi.org/http://dx.doi.org/10.23887/jet.v1i1.10077.

Peyrefitte, M., \& Lazar, G. (2018). Student-centered Pedagogy and Real-world Research: Using Documents as Sources of Data in Teaching Social Science Skills and Methods. https://doi.org/10.1177/0092055X17727835.

Rambousek, V., Štípek, J., \& Vaňková, P. (2016). Contents of Digital Literacy from the Perspective of Teachers and Pupils. Procedia - Social and Behavioral Sciences, 217, 354-362.

Shahali, E. H. M., Halim, L., Treagust, D. F., Won, M., \& Chandrasegaran, A. L. (2015). Primary School Teachers' Understanding of Science Process Skills in Relation to Their Teaching Qualifications and Teaching Experience. Research Science in Education, 47, 257-281. https://doi.org/10.1007/s11165-015-9500-z. Soto, M., \& Ambrose, R. (2016). Screencasts: Formative Assessment for Mathematical Thinking. Technology, Knowledge, and Learning, 21(2), 277-283. https://doi.org/10.1007/s10758-015-9272-6.

Staddon, J. (2017). Theoretical Behaviorism. In Behavior and Philosophy (217-241).

Suduc, A., Bizoi, M., \& Gorghiu, G. (2015). Inquiry-Based Science Learning in Primary Education. Procedia - Social and Behavioral Sciences, 205(May), 474 479. https://doi.org/10.1016/j.sbspro.2015.09.044. Susialita, T. (2016). The Development of Audio-Visual Student Portfolios (LKS) Contextual Teaching and Learning-Based (CTL) on Sound Chapter of Science Subject for Deaf Students. Jurnal Pendidikan IPA Indonesia, 5(2), 192-198. https://doi.org/10.15294/jpii.v5i2.6734 Unver, S. K. (2018). Views of Mathematics Student Teachers on Teacher Insights into the Teaching Process. International Journal of Instruction, 11(4), 689-700.

Wati, W., \& Novianti. (2016). Pengembangan Rubrik Asesmen Keterampilan Proses Sains Pada Pembelajaran IPA SMP. Jurnal Ilmiah Pendidikan Fisika A;-Biruni, 05(1), 131-140. https://doi.org/10.24042/jpifalbiruni.v5i1.113.

Yustina, K. (2017). The Implementation of Constructivism-based Student Worksheets within The Theme "The Prevention of Land and Forest 
Mudarrisa: Jurnal Kajian Pendidikan Islam, Vol. 12, No. 1, 2020

Fire" in Science Education for Seventh Graders in Riau. Jurnal Pendidikan IPA Indonesia, 6(2), 298-305.

Zulkarnaen, Imam Supardi ZA, B. J. (2017). Feasibility of Creative Exploration, Creative Modeling, Practice Scientific Creativity, Discussion, Reflection (C3PDR) Teaching Model to Improve Students' Scientific Creativity of Junior High School. Journal of Baltic Science Education, 16(6), 1020-1034. 